\title{
OPTIMALISASI KESEHATAN REPRODUKSI REMAJA PUTRI MELALUI PENDIDIKAN KESEHATAN DAN DEMONSTRASI PEMERIKSAAN PAYUDARA SENDIRI (SADARI)
}

\author{
Tri Rahayuning Lestari ${ }^{1^{*}}$, Nopita Wati ${ }^{2}$, Desak Ari Dwijayanti ${ }^{3}$, \\ Yuni Lestari ${ }^{4}$, I Gede Juanamasta ${ }^{5}$ \\ 1,2,3,4Program Studi Keperawatan, STIKes Wira Medika Bali \\ ${ }^{1}$ trilestari100@gmail.com, ${ }^{2}$ ners.pita@gmail.com, ${ }^{3}$ djdesak@gmail.com, \\ 4yunilestariwika@gmail.com, ${ }^{5}$ juana@stikeswiramedika.ac.id
}

\begin{abstract}
ABSTRAK
Abstrak:Kegiatan pengabdian ini bertujuan untuk mengoptimalkan kesehatan reproduksi wanita melalui pendidikan kesehatan dan demontrasi pemeriksaan payudara sendiri (SADARI). Metode kegiatan menggunakan (1) metode ceramah d a n demonstrasi yakni untuk menyampaikan pengetahuan secara umum tentang kanker payudara dan pemeriksaan payudara sendiri (SADARI) disertai dengan sesi tanya jawab dan (2) metode pembelajaran digunakan untuk alih pengetahuan atau ketrampilan dan system nilai yang dimiliki oleh nara sumber kepada remaja putri. Masalah yang dihadapi di lapangan adalah kurangnya pengetahuan remaja putri tentang pemeriksaan payudara sendiri (SADARI). Pemecahan masalah yang dapat dilakukan dengan pendampingan yaitu memberikan pengetahuan, pemahaman, penyuluhan dan demontrasi.
\end{abstract}

Kata Kunci: SADARI, Kanker Payudara, Pendidikan Kesehatan dan Demonstrasi.

\begin{abstract}
This service activity aims to optimize women's reproductive health through health education and breast self-examination demonstrations (BSE). The activity method uses (1) lecture and demonstration methods, namely to convey general knowledge about breast cancer and breast self-examination (BSE) accompanied by question and answer sessions and (2) learning methods used for knowledge transfer or skills and value systems owned by nara resources for young women. The problem faced in the field is the lack of knowledge of young women about breast self-examination (BSE). Problem solving that can be done with assistance is to provide knowledge, understanding, counseling and demonstration
\end{abstract}

Keywords: SADARI, Breast Cancer, Health Education and Demonstrations 


\section{A. LATAR BELAKANG}

Kanker payudara merupakan salah satu masalah kesehatan terutama pada wanita yang sampai saat ini masih menjadi penyebab kematian cukup tinggi di daerah negara-negara maju serta negara berkembang seperti di daerah Asia. Data statistik menunjukan bahwa wanita diseluruh dunia lebih banyak terserang kanker payudara dari pada tipe kanker yang lain (Bustani, 2016). World Health Organization (WHO), menunjukkan terdapat 8-9\% wanita yang mengalami kanker payudara. Kasus kanker payudara di Eropa meningkat setiap tahun lebih dari 250.000 atau setiap jam terdapat 28 kasus baru kanker payudara. Data kasus kanker payudara di Amerika kurang lebih 175.000 atau setiap jam terdapat 19 kasus baru (Rahayuwati, Ibrahim, \& Komariah, 2017). Data GLOBOCAN International Agency Research on Cancer (IARC) (2018), tentang insiden dan kematian akibat kanker yang diproduksi oleh Badan Internasional untuk Penelitian Kanker, dengan fokus pada variabilitas geografis di 20 wilayah dunia, akan ada sekitar 18,1 juta kasus kanker baru, 9,6 juta kematian akibat kanker (American Cancer Society, 2014), penyebab utama kematian akibat kanker (18,4\% dari total kematian akibat kanker), diikuti oleh kanker payudara wanita (11,6\%). American Cancer Society (2016), mengemukakan bahwa kanker payudara termasuk jenis kanker kedua yang paling mematikan setelah kanker paru-paru. Cancer Research UK di Inggris, menyatakan bahwa setiap tahun lebih dari 330.000 orang di negara tersebut didiagnosa menderita kanker. Berdasarkan angka tersebut, 30\% nya adalah penderita kanker payudara. Breast Cancer Fondation (BCF) di Singapura, memberikan data bahwa 1 dari 16 wanita didiagnosa mengidap kanker payudara (Society, 2017).

Indonesia menempati urutan kanker payudara pertama dalam 10 tahun terakhir sampai dengan tahun 2016 (Infodatin (2016) dalam Fahira (2018)). Data Riset Kesehatan Dasar tahun (2018), menunjukan prevalensi kanker di Indonesia berdasarkan diagnosis dokter pada tahun 2013 wawancara semua umur mencapai $1,4 \%$ dan pada tahun 2018 wawancara semua umur meningkat menjadi $1,8 \%$. Berdasarkan kabupaten/kota provinsi Bali diagnosis dokter pada tahun 2013 wawancara semua umur mencapai 1,8\% dan pada tahun 2018 wawancara semua umur meningkat menjadi 1,9\%. Cakupan deteksi dini kanker payudara dengan pemeriksaan klinis atau Clinical Breast Examination (CBE) pada perempuan usia 30-50 tahun menurut kabupaten/kota provinsi Bali mencapai 0,6\% per 1000 perempuan atau 34,362 perempuan. Berdasarkan data yang didapat melalui situs resmi Dinas Kesehatan Provinsi Bali tahun 2017, menunjukkan jumlah deteksi dini pada kanker payudara terendah di Denpasar mencapai 0,2\% per 1000 perempuan atau 2,836 perempuan.

Tindakan skrining yang dapat dilakukan adalah dengan Pemeriksaan Payudara Sendiri (SADARI) yang dilakukan oleh wanita mulai usia 20 tahun dan dilakukan setiap bulan, 7-10 hari setelah hari pertama haid terakhir. Hal ini disebabkan masih rendahnya kesadaran, pengertian dan pengetahuan masyarakat tentang kanker payudara (Rasjidi dalam Charisma, 2013). Pemeriksaan payudara sendiri (SADARI) adalah metode termudah, tercepat, termurah dan paling sederhana yang dapat mendeteksi secara dini adanya kelainan seperti tumbuhnya massa pada payudara. SADARI cukup dilakukan sekitar 10 - 15 menit dengan menggunakan jari- 
jari tangan untuk meraba seluruh permukaan payudara sampai kearah ketiak (Kusumawati, Mardiana, \& Hety Hasanal F, 2011). SADARI baik dilakukan rutin setiap bulannya setelah menstruasi. Kondisi payudara pada saat menstruasi lunak dan longgar sehingga memudahkan perabaan. Manfaat melakukan pemeriksaan rutin setiap bulan, maka seseorang akan semakin mengenal keadaan normal payudaranya sehingga semakin mudah menemukan massa pada payudara (Syaiful \& Aristantia, 2016).

Menurut Lawrence Green, pengetahuan adalah salah satu faktor yang mempengaruhi perubahan perilaku individu. Pengetahuan perempuan tentang risiko dan manfaat dari deteksi dini kanker payudara berpengaruh positif terhadap keyakinan mereka tentang kesehatan, sikap, dan perilaku, sehingga perawatan kesehatan professional dapat mengembangkan program kesehatan payudara yang efektif (Erbil dalam Ona, 2013). Tindakan yang berkaitan dengan upaya pencegahan dini pada wanita usia subur diharapkan pengetahuan yang cukup untuk memotivasi diri mereka dalam melakukan pemeriksaan payudara sendiri (SADARI) (Hidayati, 2016).

Lokasi Pengabdian ini berada di SMAN 1 Kuta Utara, Badung Bali. Berdasarkan hasil pra survey, permasalahan yang ada yaitu (1) siswi belum pernah mendapatkan pendidikan kesehatan terkait deteksi dini kanker payudara (2) tidak mengetahui bagaimana melakukan sadari. Melihat kondisi permasalahan diatas, maka program kegiatan yang akan dilakukan adalah mengoptimalkan kesehatan reproduksi wanita melalui pendidikan kesehatan dan demontrasi pemeriksaan payudara sendiri (SADARI) (Hidayati, Salawati, \& Istiana, 2013).

Adapun tujuan kegiatan ini yakni (1) Meningkatkan pengetahuan remaja putri mengenai kanker payudara, (2) Meningkatkan pengetahuan dan keterampilan remaja putri dalam melakukan pemeriksaan payudara sendiri (SADARI) (3) Meningkatkan kesadaran remaja putri untuk melakukan pemeriksaan payudara sendiri (SADARI) (4) Terjalinnya kerjasama perguruan tinggi, sekolah dan masyarakat dalam rangka pemberdayaan remaja putri untuk melakukan pemeriksaan payudara sendiri (SADARI).

\section{B. METODE PELAKSANAAN}

Untuk menunjang kegiatan ini maka digunakan metode yang mendukung pelaksanaan kegiatan tersebut. Berikut ini adalah rincian metode pelaksanaan yang akan dilakukan yaitu:

1. Metode pengumpulan data

Digunakan untuk mengumpulkan data-data mengenai kegiatan yang sudah dan akan dilakukan pada remaja putri serta permasalahanpermasalahan kesehatan reproduksi wanita yang dialami dan belum terselesaikan.

2. Menentukan tema kegiatan yang akan diberikan.

Berdasarkan atas apa yang telah dilakukan dalam survei yang diuraikan secara rinci pada latar belakang sehingga tema kegiatan dapat segera ditentukan.

3. Mencari studi pustaka. 
Studi pustaka adalah teknik pengumpulan data referensi dari berbagai jenis sumber keilmuan yang menunjang permasalahan yang sedang dicarikan solusinya.

4. Membuat materi penyuluhan atau pelatihan.

Berdasarkan studi pustaka yang telah dilakukan maka dibuatlah materi penyuluhan dan demontrasi.

5. Menyajikan penyuluhan dan demontrasi.

Penyuluhan atau demontrasi diberikan dengan metode ceramah dan demontrasi langsung akan materi tersebut.

\section{HASIL DAN PEMBAHASAN}

Lokasi Abdimas berada di SMAN 1 Kuta Utara, berlokasi di Jalan Made Bilet nomor 19 Dalung, Kuta Utara Badung Bali. Berdasarkan hasil pra survey, permasalahan yang ada yaitu (1) siswi belum pernah mendapatkan pendidikan kesehatan terkait deteksi dini kanker payudara (2) tidak mengetahui bagaimana melakukan sadari. Melihat kondisi permasalahan diatas, maka program kegiatan yang akan dilakukan adalah mengoptimalkan kesehatan reproduksi wanita melalui pendidikan kesehatan dan demontrasi pemeriksaan payudara sendiri (SADARI). Pemecahan masalah yang dapat dilakukan yaitu memberikan pengetahuan, pemahaman, dan pelatihan mengenai pemeriksaan payudara sendiri (SADARI). Adapun uraian kegiatan yang telah dilakukan, yaitu:

\section{Pre-test.}

Setelah dilakukan pra-survey melalui diskusi dan observasi terhadap siswi di sekolah, tahap berikutnya dari kegiatan ini yaitu pre-test terhadap 30 orang siswi. Kegiatan ini dilaksanakan dengan cara memberikan kuesioner.

Tabel 1. Hasil Pre-test

\begin{tabular}{ccc}
\hline Pengetahuan (Pre Test) & Frekuensi & Presentase (\%) \\
\hline Kurang & 21 & 70 \\
\hline Cukup & 8 & 27 \\
\hline Baik & 1 & 3 \\
\hline Total & 30 & 100 \\
\hline
\end{tabular}

Hasil pre-test menunjukkan bahwa sebagian siswi memiliki pengetahuan kurang yaitu sebanyak 21 orang (70\%). Notoatmodjo (2011), pengetahuan merupakan hasil dari 'tahu' dan ini terjadi setelah orang melakukan penginderaan terhadap objek tertentu. Penginderaan terjadi melalui panca indera manusia, yakni indera pengelihatan, pendengaran, penciuman, rasa dan raba. Sebagian besar pengetahuan manusia diperoleh melalui mata dan telinga.

Menurut Notoatmodjo (2012) untuk mendapatkan pengetahuan dapat dipengaruhi oleh alat bantu atau media yang menjadi alat penyampaian informasi. Media disusun berdasarkan prinsip bahwa pengetahuan yang ada pada setiap manusia diterima melalui panca indera. Semakin banyak panca indera yang digunakan untuk menerima sesuatu maka semakin banyak dan semakin jelas pula pengetahuan yang diperoleh. Salah satu media yang menggunakan dua panca indera sekaligus adalah media audio visual, dimana dengan 
media ini infomasi disampaikan menggunakan suara dan gambar sehingga penerima informasi akan menggunakan panca indera pengelihatan dan pendengaran untuk mendapatkan pengetahuan dari informasi yang disampaikan. Pada penelitian ini mayoritas siswi belum pernah mendapatkan informasi tentang pemeriksaan payudara sendiri (SADARI) melalui media audio visual maupun media lainnya.

Hal ini sejalan dengan penelitian oleh Suastina (2013), hasil penelitian tersebut mendapatkan remaja putri di SMA Negeri 1 Manado sebagian besar memiliki pengetahuan kurang tentang SADARI yaitu sebanyak 61 orang responden (62,9\%) dari jumlah keseluruhan responden 97 orang (Suatina, 2013). Hasil penelitian yang dilakukan oleh Mardiyana (2015) juga mendapatkan pengetahuan yang kurang pada remaja putri tentang SADARI sebelum diberikan pendidikan kesehatan yaitu sebesar 35 orang responden (85\%). Penelitian Hidayati (2014) menyatakan bahwa saat dilakukan pre test semua responden memiliki pengetahuan kurang yaitu 55 orang (100\%) akibat kurangnya responden terpapar oleh informasi melalui mediamedia (Hidayati, 2016). Menurut penelitian Suhita (2013) dari jumlah total sampel 99 orang terdapat 71 orang yang memiliki pengetahuan kurang pada hasil pre test. Kedua penelitian tersebut menyebutkan bahwa sebelum diberikan pendidikan kesehatan, siswi memiliki pengetahuan yang kurang tentang SADARI. Septiani (2013) mengatakan bahwa faktor tertinggi yang menyebabkan seorang wanita tidak melakukan SADARI adalah karena pengetahuan yang rendah.

Dilihat dari data tingkat pengetahuan sebelum diberikan pendidikan kesehatan melalui media audio visual adalah remaja putri cenderung memiliki pengetahuan yang kurang karena kurang terpapar informasi melalui media yang salah satunya media audio visual. Selain itu, faktor lain yang dapat mempengaruhi pengetahuan remaja putri menjadi kurang adalah motivasi yang kurang untuk mengetahui atau belajar tentang SADARI dan kurangnya dukungan dari lingkungan rumah maupun sekolah.

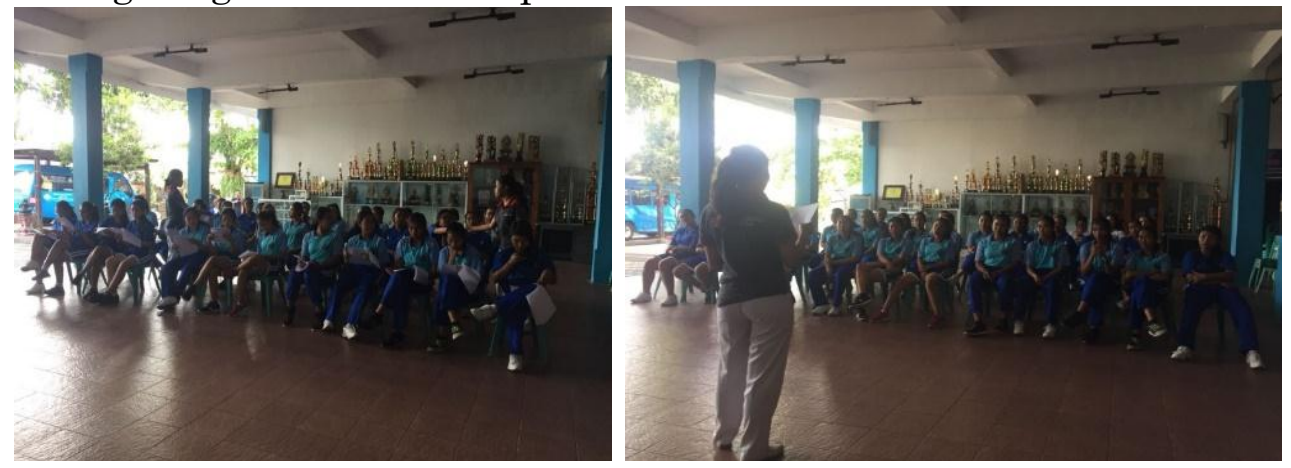

Gambar 1. Kegiatan Pre-Test

2. Penyuluhan dan Demontrasi Kegiatan Pemeriksaan Payudar Sendiri (SADARI)

Pelaksanaan penyuluhan dan demontrasi kegiatan pemeriksaan payudara sendiri (SADARI) dilakukan di aula sekolah SMAN 1 Kuta Utara. 
Tabel 2. Perbedaan Pre-Test dan Post-Test

\begin{tabular}{lcc}
\hline $\begin{array}{l}\text { Perbedaan tingkat pengetahuan } \\
\text { pre test dan post test }\end{array}$ & Jumlah (N) & Asymp.Sig. \\
\hline Negatif ranks & 0 & \\
Positif ranks & 26 & 0,000 \\
Ties & 4 & \\
\hline Total & 30 & \\
\hline
\end{tabular}

Berdasarkan hasil yang didapat menggunakan uji Wilcoxon Sign Rank Test diperoleh nilai sebesar $\mathrm{p}=0,000<\mathrm{\alpha}(\mathrm{\alpha}=0,05)$ yang berarti Ho ditolak atau dapat disimpulkan bahwa ada pengaruh pendidikan kesehatan dengan media audio visual terhadap pengetahuan remaja putri tentang pemeriksaan payudara sendiri (SADARI).

Hal ini sejalan dengan teori yang dikemukakan oleh Mubarak (2011) yang menyatakan bahwa ada tujuh faktor yang mempengaruhi tingkat pengetahuan dan salah satunya adalah informasi. Penyampaian informasi dalam penelitian ini dilakukan melalui pendidikan kesehatan, dimana pendidikan kesehatan merupakan intervensi atau upaya yang ditujukan kepada masyarakat agar masyarakat mampu melakukan tindakan-tindakan yang mampu memelihara maupun meningkatkan kesehatan (Notoatmodjo, 2012). Menurut Notoatmodjo (2011) pengetahuan merupakan hasil dari 'tahu' dan ini terjadi setelah orang melakukan penginderaan terhadap suatu objek. Penginderaan ini dapat dilakukan melalui media-media dalam penyampaian pendidikan kesehatan. Media yang digunakan dalam penelitian ini yaitu audio visual, dimana media audio visual merupakan media yang memiliki unsur suara dan unsur gambar dengan penyampaian melalui mesin mekanis atau elektronik.

Penelitian ini didukung oleh Suastina (2013) dimana pada penelitian tersebut diperoleh data peningkatan pengetahuan yang terjadi sebelum diberikan perlakuan dan setelah diberikan perlakuan. Sebelum diberikan perlakuan, data pre test yang didapatkan yaitu 61 orang berpengetahuan kurang, sedangkan setelah diberikan perlakuan berupa pendidikan kesehatan didapatkan data post test yaitu 79 orang berpengetahuan baik dan hanya 6 orang yang berpengetahuan buruk. Hasil uji Wilcoxon Signed Rank Test didapatkan nilai sebesar p=0,000 $<\alpha(\alpha=0,05)$, yang berarti Ho ditolak atau dapat disimpulkan bahwa ada pengaruh pendidikan kesehatan terhadap tingkat pengetahuan siswi tentang SADARI sebagai deteksi dini kanker payudara di SMA Negeri 1 Manado. Hal ini juga sejalan dengan penelitian Mardiyana (2015) yang mengatakan ada pengaruh pendidikan kesehatan terhadap tingkat pengetahuan tentang pemeriksaan payudara sendiri (SADARI) pada remaja putri di Dusun Keret Desa Sumberjati, Mojoanyar Mojokerto. Kedua penelitian tersebut membuktikan bahwa ada pengaruh pendidikan kesehatan terhadap peningkatan pengetahuan. Menurut Sulistyowti (2016) pemberian pendidikan kesehatan berpengaruh pada pengetahuan siswi di SMK 1 Muhamadiyah Lamongan tentang bagaimana cara melakukan SADARI dengan benar. Menurut Suhita (2013) terdapat perbedaan yang signifikan antara pengetahuan remaja putri sebelum diberikan pendidikan kesehatan 
dan sesudah diberikan pendidikan kesehatan, dimana pengetahuan remaja putri stetelah diberikan pendidikan kesehatan mengalami peningkatan. Menurut Alini (2018) pemberian pendidikan kesehatan dengan media audio visual sangat efektif dalam meningkatkan pengetahuan remaja putri tentang SADARI dilihat dari adanya peningkatan pengetahuan yang terjadi setelah remaja putri diberikan informasi melalui media audio visual (Alini, 2018).

Informasi yang diberikan melalui pendidikan kesehatan dengan media audio visual dapat meningkatkan pengetahuan remaja putri tentang SADARI. Pendidikan kesehatan dengan media audio visual mampu merangsang indera pengelihatan dan pendengaran responden untuk menangkap sebuah pengetahuan baru sehingga dapat meningkatkan pengetahuan pada responden tersebut. Pemberian pendidikan kesehatan dengan media audio visual mampu memberikan peningkatan pada pengetahuan remaja putri tentang pemeriksaan payudara sendiri (SADARI), terbukti dengan hasil post test yang mengalami peningkatan nilai responden yang menjawab benar dibandingkan dengan hasil pre test yang didapat sebelum diberikan pendidikan kesehatan.

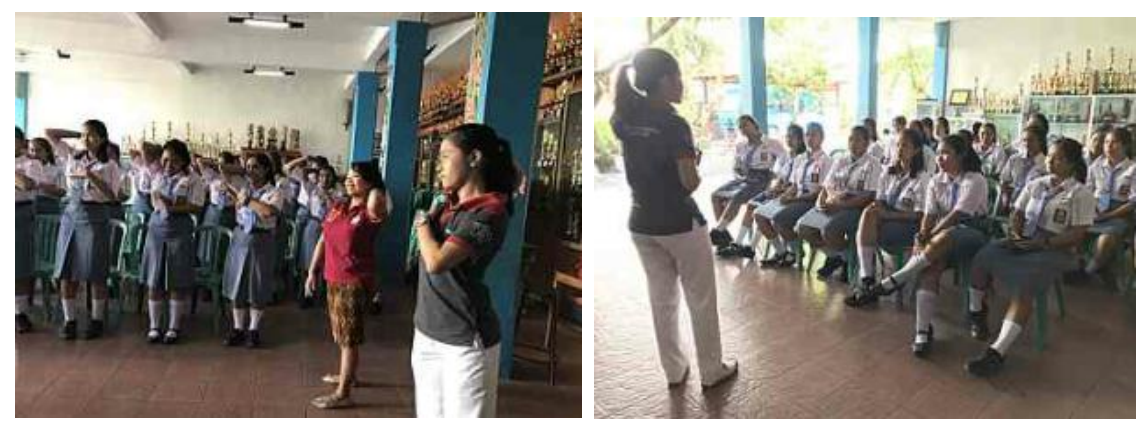

Gambar 2. Pelaksanan penyuluhan dan demontrasi SADARI

\section{Post-Test}

Setelah dilakukan penyuluhan dan demontrasi di sekolah, tahap berikutnya dari kegiatan ini yaitu post-test kembali dengan cara memberikan kuesioner.

\begin{tabular}{ccc}
\multicolumn{4}{c}{ Tabel 3. Hasil Post-Test } \\
\hline Pengetahuan (Post Test) & Frekuensi & Presentase (\%) \\
\hline Kurang & 0 & 0 \\
\hline Cukup & 4 & 13 \\
\hline Baik & 26 & 87 \\
\hline Total & 33 & 100
\end{tabular}

Setelah dilakukan pendidikan kesehatan, pengetahuan yang dimiliki remaja putri di SMAN 1 Kuta Utara mengalami peningkatan. Hal ini disebabkan karena remaja putri telah mengalami proses untuk mengetahui sesuatu. Remaja putri dapat mengalami proses tersebut karena adanya perlakuan yang diberikan yaitu berupa pendidikan kesehatan dengan media audio visual.

Audio visual memberikan kontribusi yang sangat besar dalam perubahan perilaku masyarakat, terutama dalam aspek informasi dan 
persuasi. Media audio visual memiliki dua elemen yang masing masing mempunyai kekuatan yang akan bersinergi menjadi kekuatan yang besar. Media ini memberikan stimulus pada pendengaran dan penglihatan, sehingga hasil yang diperolah lebih maksimal. Hasil tersebut dapat tercapai karena pancaindera yang paling banyak menyalurkan pengetahuan ke otak adalah mata (kurang lebih $75 \%$ sampai $87 \%$ ) sedangkan $13 \%$ sampai $25 \%$ pengetahuan diperoleh atau disalurkan melalui indera yang lain.

Hal ini sejalan dengan penelitian yang dilakukan oleh Suastina (2013) dimana diperoleh hasil dari total responden 97 orang didapatkan peningkatan pengetahuan dari sebelum diberikan perlakuan hasil pre test total responden berpengetahuan kurang berjumlah 61 orang (62,9\%). Setelah diberikan perlakuan hasil post test mengalami perubahan yaitu sebagian besar responden memiliki pengetahuan baik berjumlah 79 orang $(81,4 \%)$. Hasil penelitian Suastina menyatakan bahwa setelah diberikan pendidikan kesehatan pengetahuan siswi yang diukur menggunakan kuesioner semakin meningkat menjadi baik. Menurut Ropa Shorea (2014) mengatakan bahwa setelah responden diberikan promosi kesehatan dengan media audio visual, responden yang pada awalnya memiliki pengetahuan kurang berubah menjadi pengetahuan yang baik. Menurut Hidayati (2016) informasi sangat mempengaruhi pengetahuan seseorang sehingga terjadi perubahan pengetahuan dari mayoritas berpengetahuan kurang pada saat pre test berubah menjadi mayoritas berpengetahuan baik pada saat post test (Hidayati, 2016). Menurut Utari (2013) mengatakan bahwa rendahnya pengetahuan wanita tentang kanker payudara dan SADARI berakibat pada kesadaran dan sikap wanita dalam melakukan SADARI, dan salah satu penyebab kurangnya pengetahuan wanita tentang SADARI adalah kurangnya penyuluhan atau pendidikan kesehatan yang diberikan pada wanita. Menurut Yanti (2015) pemberian pendidikan kesehatan dengan media audio visual mampu meningkatkan pengetahuan. Hal ini disebabkan karena siswi telah mendapatkan intervesi berupa pendidikan kesehatan dengan media audio visual tentang pemeriksaan payudara sendiri (SADARI). Intervensi pendidikan kesehatan dengan media audio visual yang diberikan merupakan sebuah bentuk penyampaian informasi yang menjadi salah satu faktor yang mempengaruhi pengetahuan siswi. Melalui informasi yang diberikan oleh peneliti, siswi mengalami sebuah proses untuk mengetahui sesuatu sehingga menyebabkan adanya perubahan pada pengetahuan siswi. Selain itu, pada saat intervensi dilakukan siswi atau remaja putri tampak antusias dan konsentrasi mendengarkan sehingga informasi yang disampaikan melalui video dapat diterima dengan baik dan memberikan peningkatan pada hasil post test. 


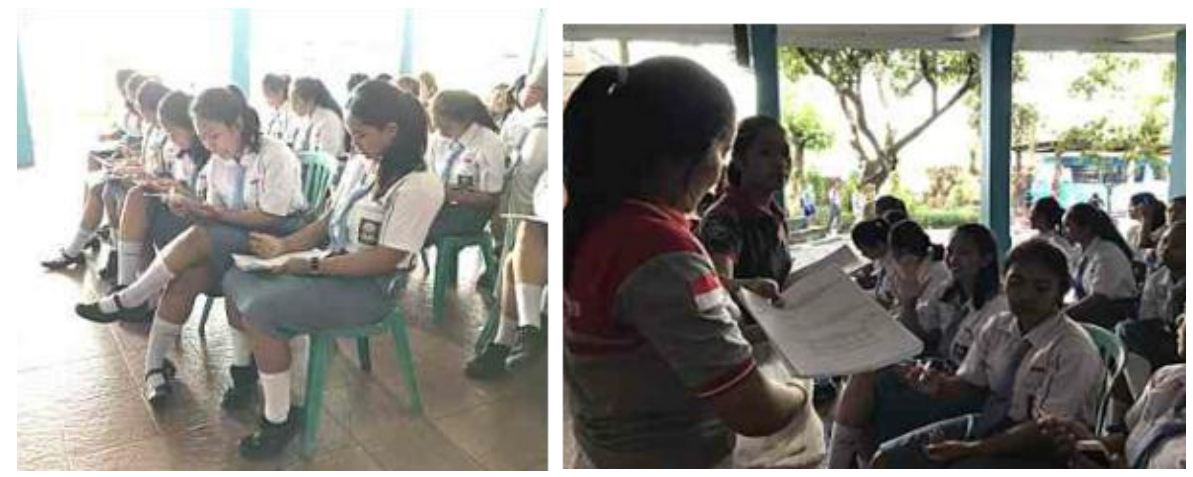

Gambar 3. Kegiatan Post-Test

\section{SIMPULAN DAN SARAN}

Simpulan yang kami dapatkan dalam kegiatan ini adalah kegiatan pengabdian kepada masyarakat di SMAN 1 Kuta Utara, Badung Bali mendapat sambutan, tanggapan dan perhatian yang cukup baik dari siswi, guru dan pihak sekolah setempat, program kegiatan yang diberikan kepada masyarakat dapat terealisasi dengan optimal dan lancar, bekal yang diberikan kepada masyarakat pada dasarnya, memberikan dukungan dan pengetahuan yang berdampak dampak positif, kegiatan pengabdian kepada masyarakat mempunyai tujuan di antaranya menjalin erat hubungan antara lembaga perguruan tinggi sebagai sumber ilmu pengetahuan dengan masyarakat dan pemerintah setempat terintegrasi dengan baik. Dapat disimpulkan juga bahwa pada saat pre test mayoritas siswi berpengetahuan kurang yaitu 21 (70\%) orang, setelah diberikan pendidikan kesehatan didapatkan hasil post test bahwa mayoritas siswi memiliki pengetahuan baik yaitu $26(87 \%)$ orang. Sedangkan saran yang dapat kami berikan yaitu kepada pihak sekolah agar ikut berperan dalam penyampaian informasi kesehatan kepada seluruh siswa/siswi guna meningkatkan pengetahuan siswa/siswi tentang kesehatan.

\section{UCAPAN TERIMA KASIH}

Ucapan terima kasih kami sampaikan kepada semua pihak yang telah membantu pelaksanaan kegiatan pengabdian kepada masyarakat ini, yaitu: (1) Kepala S M A N 1 Ku ta Utar a dan jajarannya serta siswi setempat atas perhatian dan kerjasamanya sehingga kami dapat melaksanakan kegiatan ini, (2) Lembaga Pengabdian Pada Masyarakat (LPPM) STIKes Wira Medika Bali yang telah mendanai kegiatan pengabdian ini sehingga terlaksana dengan baik. (3) Tim dosen dan mahasiswa/I yang telah membantu dalam kegiatan pengabdian kepada masyarakat ini, dan semua pihak yang telah membantu dalam pelaksanaan kegiatan ini, yang tidak bisa kami sebutkan satu persatu.

\section{DAFTAR RUJUKAN}

Alini. (2018). Efektifitas Promosi Kesehatan Melalui Audio Visual dan Leaflet Tentang Sadari (Pemeriksaan Payudara Sendiri) Terhadap Peningkatan Pengetahuan Remaja Putri Tentang Sadari Di SMAN 1 Kampar Tahun 2018. Jurnal Ners Universitas Pahlawan, 2(2), $1-9$.

American Cancer Society. (2014). Breast Cncer (Facts \& Figures). American Cancer Society, 
38. https://doi.org/10.1007/978-1-4614-8063-1

Bustani, E. R. (2016). Penggunaan Pengobatan Alternatif Sebagai Faktor Risiko Keterlambatan Penderita Kanker Payudara Melakukan Pengobatan Di Surakarta. Jurnal UPT Perpustakaan Universitas Sebelas Maret.

Hidayati, A. (2016). Pengaruh Pendidikan Kesehatan Melalui Metode Ceramah dan Demonstrasi Dalam Meningkatkan Pengetahuan Pasien Dalam Penurunan Kecemasan. Journal of Caring Sciences, 1(1), 1-8.

Hidayati, A., Salawati, T., \& Istiana, S. (2013). Pengaruh Pendidikan Kesehatan Melalui Metode Ceramah Dan Demonstrasi Dalam Meningkatkan Pengetahuan Tentang Kanker Payudara Dan Keterampilan Melakukan SADARI. Jurnal Kebidanan, 1(1), 1-8.

KUSUMAWATI, E., Mardiana, M., \& Hety Hasanal F, H. H. (2011). Gambaran Tingkat Pengetahuan Remaja Putri Tentang Pemeriksaan Payudara Sendiri (SADARI). Jurnal Penelitian Kesehatan, 2(1).

Rahayuwati, L., Ibrahim, K., \& Komariah, M. (2017). Pilihan Pengobatan Pasien Kanker Payudara Masa Kemoterapi: Studi Kasus. Jurnal Keperawatan Indonesia, 20(2), 118-127. https://doi.org/10.7454/jki.v20i2.478

Society, A. C. (2017). Breast Cancer Facts and Figures 2017-2018. In Atlanta: American Cancer Society, Inc. https://doi.org/10.1016/B978-0-323-48567-8.00003-1

Suastina. (2013). Pengaruh Pendidikan Kesehatan Terhadap Tingkat Pengetahuan Siswi Tentang Sadari Sebagai Deteksi Dini Kanker Payudara Di SMA Negeri 1 Manado. (2013). Jurnal Keperawatan, 1(1).

Syaiful, Y., \& Aristantia, R. (2016). Pendidikan Kesehatan Pemeriksaan payudara Sendiri Terhadap Perilaku SADARI pada Remaja. Journal Of Ners Community, 07(November), 113-124. 